\title{
Kemampuan Insulasi Suara Delapan Jenis Bahan Berbasis Serat Kayu
}

\author{
Sound Insulation Ability of Eight Wood Fiber Based Materials
}

\author{
F. Dwi Joko Priyono*, Yusdiansyah \\ Program Studi Rekayasa Kayu, Politeknik Pertanian Negeri Samarinda, Indonesia.
}

*Corresponding Author: jokopoltanesa@gmail.com

\begin{abstract}
Abstrak
Semakin berkembangnya aktivitas manusia menyebabkan berbagai gangguan kesehatan dan kenyamanan lingkungan seperti kebisingan. Gangguan tersebut dapat dieliminasi dengan memanfaatkan berbagai bahan insulasi yang mampu mencegah kebocoran suara antar ruang. Kemampuan insulasi suara dari suatu bahan ditunjukkan dengan besarnya nilai koefisien peredaman suara ( $\alpha$ ). Sebanyak delapan jenis bahan berserat dicobakan dalam penelitian dengan maksud mengetahui fungsinya sebagai material insulasi suara. Bahan tersebut terdiri atas karton (kardus), tatakan telur, kayu akasia, kayu sengon, papan partikel, papan gypsum dan kayu lapis. Semua bahan dibentuk lempengan dengan ukuran diameter $10 \mathrm{~cm}$. Lempeng difungsikan sebagai insulator di tengah antar ruang pada sebuah tabung PVC yang di satu ujungnya dipasang bel pintu sebagai sumber suara dan ujung pipa lainnya dipasang alat Sound Level Meter (SLM) sebagai penerima suara. Nilai koefisien peredaman dihitung menurut Lewis dan Douglas (1993). Hasil penelitian menunjukkan bahwa nilai koefisien peredaman tertinggi dan material dengan jumlah signifikan terbanyak diperoleh dari material kayu akasia mangium, kemudian berturut-turut diikuti oleh papan partikel tebal, papan partikel tipis, kayu sengon, kayu lapis, gypsum, tatakan telur dan karton, dengan rentang nilai $\alpha$ antara 0,13 sampai dengan 0,06 .
\end{abstract}

Kata kunci: Insulasi, koefisien peredaman suara.

\begin{abstract}
The development of human activities has caused various health problems and environmental comfort such as noise. These disturbances can be eliminated by utilizing various insulation materials that can prevent sound leakage between rooms. The sound insulation ability of a material is indicated by the value of the sound attenuation coefficient $(\alpha)$. A total of eight types of fibrous materials were tested in this study with the aim of knowing their function as sound insulation materials. These materials consist of cardboard, egg mat, acacia wood, sengon wood, particle board, gypsum board and plywood. All materials were formed into slabs with a diameter of $10 \mathrm{~cm}$. The slab was used as an insulator in the middle between spaces in a PVC tube with a doorbell installed at one end as a sound source and at the other end a Sound Level Meter (SLM) device was installed as a sound receiver. The damping coefficient value was calculated according to Lewis and Douglas (1993). The results showed that the highest damping coefficient value and the material with the highest significant amount were obtained from Acacia mangium wood material, followed by thick particle board, thin particle board, sengon wood, plywood, gypsum, egg mat and cardboard, with a range value of 0.13 to 0.06 .
\end{abstract}

Keywords: Insulation, sound attenuation coefficient.

\section{PENDAHULUAN}

Dengan semakin padatnya penduduk dan meningkatnya aktivitas manusia akan menghasilkan suara yang tidak dikehendaki atau menimbulkan suatu gangguan. Untuk mengatasi hal tersebut dikembangkan berbagai bahan peredam suara guna mendukung penciptaan ruang dengan karakteristik akustik tertentu sehingga memberikan kenyamanan bagi penggunanya (Wijaya, 2005).
Insulasi suara bertujuan untuk mencegah, mengurangi kebocoran suara dari suatu ruang ke ruang lainnya. Definisi teknisnya ialah bahan yang dapat menginsulasi perpindahan suara. Peredaman serap suara bertujuan untuk mengurangi pantulan yang menyebabkan gema dari suatu ruang, atau bahan yang mampu menyerap energi suara.

Kualitas dari bahan peredam suara ditunjukkan dengan harga a (koefisien penyerapan bahan terhadap bunyi), dimana 
semakin besar nilai a maka bahan peredam semakin baik (Giri, 2008).

Adsorbsi (penyerapan atau peredaman) bunyi adalah perubahan energi bunyi menjadi suatu bentuk lain, biasanya berbentuk panas ketika melewati suatu bahan atau ketika menumbuk suatu permukaan. Bila bunyi menumbuk suatu permukaan maka akan dipantulkan atau diserap (Simatupang, 2011). Jenis bahan peredam suara yang sudah biasa digunakan antara lain bahan berpori, resonator dan panel (Lee, 2003), dan dari ketiga bahan tersebut bahan berporilah yang sering digunakan khususnya untuk mengurangi kebisingan pada suatu ruang yang sempit seperti perumahan atau perkantoran. Hal tersebut disebabkan bahan berpori lebih murah dan ringan dibanding jenis peredam lainnya.

Penelitian ini bertujuan untuk mengetahui karakter delapan jenis bahan yang terdiri atas dua jenis limbah (karton dan tatakan telur), dua jenis kayu (akasia dan sengon) dan empat jenis panel kayu yang terdiri atas kayu lapis, dua jenis papan partikel yang berbeda kerapatannya, dan papan gypsum. Penelitian berusaha memperoleh nilai a dari bahan yang diteliti sehingga mendapatkan data dan peluang penggunaannya sebagai bahan insulasi.

\section{Kebisingan}

Kebisingan merupakan bunyi yang mengganggu. Definisi kebisingan menurut Hidayati (2007) adalah bunyi yang tidak diinginkan oleh suatu kegiatan atau usaha dalam tingkat dan waktu tertentu, yang menimbulkan gangguan kesehatan manusia dan kenyamanan lingkungan. Untuk meminimalisir kebisingan perlu adanya suatu peredaman bunyi.

Dampak kebisingan dapat memberikan efek negatif diantaranya menyebabkan perlemahan saat mendengarkan, gangguan komunikasi, gangguan tidur, penyebab terhadap efek jantung atau urat darah dan efek psiko-fisiologi, menurunkan performansi fisik dan menimbulkan respon kejengkelan serta perubahan perilaku sosial (WHO, 2001). Selanjutnya Setiawan (2010) memaparkan dua jenis dampak kebisingan yakni akibat pada badaniah dan akibat pada psikologis penderita. Akibat badaniah seperti kehilangan pendengaran, penurunan ambang batas kemampuan pendengaran sampai dengan kehilangan pendengaran secara permanen. Untuk akibat psikologis adalah seperti gangguan emosional, kebingungan, kejengkelan, gangguan gaya hidup (tidur, istirahat, kehilangan konsentrasi), atau kesulitan dalam pemahaman komunikasi.

\section{Koefisien Adsorbsi Bunyi}

Koefisien adsorbsi bunyi didefinisikan sebagai perbandingan antara energi bunyi yang diserap dengan energi bunyi yang datang pada permukaan material (Mediastika, 2005). Kondisi bunyi dalam ruang tertutup biasanya dianalisa dalam beberapa sifat bunyi, dan menurut Suptandar (2004) sifat tersebut antara lain bunyi langsung, bunyi pantulan (refleksi), bunyi yang diserap (absorbsi), bunyi yang disebar (difusi), bunyi yang dibelokkan (difraksi) dan bunyi yang diteruskan (transmisi).

Proporsi energi bunyi yang dipantulkan, diserap dan diteruskan ditentukan oleh koefisien serap $(\alpha)$. Koefisien serap adalah angka tanpa satuan yang menunjukkan perbandingan antara energi bunyi yang tidak dipantulkan (diserap) oleh material pembatasberbanding keseluruhan energi bunyi yang mengenai material pembatas tersebut. Sarwono (2008) menyatakan nilai batas a adalah 0,2 dimana bila mencapai nilai tersebut maka bahan dapat dikategorikan sebagai peredam yang baik, sementara Wahyudi et al (2013) menyatakan nilai minimal a adalah 0,3 untuk dapat dipakai sebagai peredam yang baik. Nilai yang diperoleh oleh peneliti Puspitarini et al., (2014) yang meneliti limbah ampas tebu sebagai bahan insulasi menghasilkan nilai $\alpha$ $=0,18$ pada sampel yang berketebalan 0,76 $\mathrm{cm}$.

\section{Sound Meter Level}

Standar alat untuk mengukur kebisingan adalah Sound Level Meter (SLM). Mekanisme kerja SLM adalah bila ada benda bergetar, maka akan menyebabkan terjadinya perubahan tekanan udara yang mana perubahan tersebut dapat ditangkap sehingga menggerakkan petunjuk nilai penerimaannya. SLM mampu mengukur kebisingan antara 30-130 dB atau frekuensi 20 - 20.000 Hz (Djalante, 2010). Pengukuran kebisingan dapat dilakukan dengan cara sederhana yakni mengukur tingkat tekanan bunyi $\mathrm{dB}$ dengan pembacaan selama 5 detik dengan beberapa ulangan, dan pada tingkat 
kekerasan bunyi sebesar $40-100 \mathrm{~dB}$ sebagai tingkat kekerasan yang mendekati tanggapan frekuensi telinga manusia (Prasetio, 1985).

\section{METODE PENELITIAN}

\section{A. Waktu dan Tempat Penelitian}

Penelitian dilakukan selama kurun waktu Januari - Juni 2021, dimulai dari pengumpulan bahan, pencarian alat penelitian, pengolahan bahan, pengujian dan pengolahan data. Peneliaian dilaksanakan di Laboratorium Rekayasa Pengolahan Kayu Politeknik Pertanian Negeri Samarinda.

\section{B. Bahan dan Peralatan Penelitian}

1. Bahan Penelitian

Bahan penelitian berupa delapan jenis insulasi terdiri atas:

a. Kardus berketebalan $0,15 \mathrm{~cm}$

b. Tatakan telur ketebalan $0,2 \mathrm{~cm}$, berlekuk

c. Kayu akasia mangium ketebalan 1,77 $\mathrm{cm}$ kerapatan $0,59 \mathrm{~g} / \mathrm{cm} 3$.

d. Kayu sengon ketebalan 2,6 cm kerapatan 0,32 $\mathrm{g} / \mathrm{cm} 3$.

e. Papan partikel ketebalan 0,21 dan $1,25 \mathrm{~cm}$ kerapatan masing-masing 0,43 dan $0,49 \mathrm{~g} / \mathrm{cm} 3$

f. Papan gypsum ketebalan $0,83 \mathrm{~cm}$ kerapatan 0,23 g/cm3

g. Kayu lapis (3 lapisan) ketebalan 0,21 $\mathrm{cm}$ kerapatan $0,52 \mathrm{~g} / \mathrm{cm} 3$.

h. Pipa PVC diameter $10 \mathrm{~cm}$ panjang 50 $\mathrm{cm}$

2. Alat Penelitian

a. Sound Level Meter (SLM)

b. Sumber bunyi (bel pintu) lengkap dengan baterai

c. Alat tulis dan pengolah data.

\section{Prosedur Penelitian}

1. Persiapan
Semua bahan yang terkumpul kemudian dibuat lempeng silinder berdiamater $10 \mathrm{~cm}$ disesuaikan dengan diameter pipa PVC, dan harus dapat dipasang tepat pada lubang PVC tanpa ada celah kosong.

2. Pelaksanaan Pengujian

Bahan peredam dipasang di tengah pipa sehingga mampu berfungsi sebagai peredam. Sumber bunyi dihidupkan pada ujung pipa dan nilai penerimaan bunyi dapat diukur sesuai dengan panel petunjuk digital yang tertera pada alat SLM yang dipasang di ujung pipa lainnya.

\section{Pengolahan Data}

Data yang diambil adalah nilai yang tercatat pada SLM untuk 8 sample dengan ulangan masing-masing sebanyak 10 kali. Nilai koefisien serapan bunyi dihitung menurut Lewis dan Douglas (1993) sebagai berikut:

$I=I_{0} \cdot \mathrm{e}^{-\mathrm{ax}}$, dimana:

$I$ = intensitas akhir $(\mathrm{dB})$, setelah dipasang peredam

$I_{0}=$ intensitas awal $(\mathrm{dB})$, sebelum dipasang peredam

$\alpha=$ koefisien absorbsi bunyi

$\mathrm{x}=$ ketebalan sample $(\mathrm{cm})$

Data yang diperoleh kemudian dihitung nilai rataannya dan diuji dengan menggunakan Rancangan Acak Lengkap (RAL) dan uji lanjut LSD (Least Significant Difference) guna mengetahui perbedaan antar perlakuan yang diterapkan.

\section{HASIL DAN PEMBAHASAN}

\section{A. Hasil}

Nilai besaran bunyi yang diterima pada alat SLM untuk ke delapan bahan (dari 10 kali ulangan) dapat ditabulasikan sebagaimana Tabel 1 berikut:

Tabel 1. Nilai Penerimaan Bunyi (dB) Bahan Insulasi

\begin{tabular}{cccccccccc}
\hline Jenis Bahan & lo & 1 & 2 & 3 & 4 & 5 & 6 & 7 & 8 \\
\hline Rataan & 111.35 & 99.11 & 96.44 & 85.68 & 88.77 & 92,66 & 95.3 & 86.23 & 93.25 \\
Xmax & 118.3 & 104.3 & 99.3 & 93.2 & 95.8 & 104.5 & 101.5 & 89.3 & 98.1 \\
Xmin & 101.3 & 93.5 & 90.3 & 77.7 & 80.9 & 82.6 & 92.5 & 78.5 & 84.5 \\
x (cm) & 0 & 0.15 & 0.2 & 1.77 & 2.6 & 0.21 & 0.83 & 1.25 & 0.21 \\
e & 2.71 & 2.71 & 2.71 & 2.71 & 2.71 & 2.71 & 2.71 & 2.71 & 2.71 \\
\hline
\end{tabular}

Ket: $1=$ karton, 2 = tatakan telur, $3=$ kayu akasia, $4=$ kayu sengon, $5=$ papan partikel, $6=$ gypsum, $7=$ papan partikel tebal, 8 = kayu lapis; $\mathrm{X}=$ tebal bahan, $\mathrm{e}=$ nilai konstanta euler. 
Tabel 2. Nilai $\alpha$ (Koefisien Peredaman) Setiap Bahan Insulasi

\begin{tabular}{lcccccccc}
\hline Jenis Bahan & 1 & 2 & 3 & 4 & 5 & 6 & 7 & 8 \\
\hline Rataan & 0.06 & 0.07 & 0.13 & 0.11 & 0.09 & 0.08 & 0.13 & 0.09 \\
Max & 0.12 & 0.13 & 0.21 & 0.17 & 0.15 & 0.12 & 0.15 & 0.13 \\
Min & 0.00 & 0.02 & 0.05 & 0.04 & 0.02 & 0.04 & 0.08 & 0.05 \\
\hline
\end{tabular}

Ket: 1= karton, 2 = tatakan telur, 3 = kayu akasia, 4 = kayu sengon, 5 = papan partikel, 6 = gypsum,

7 = papan partikel tebal, $8=$ kayu lapis.

Selanjutnya hasil perhitungan nilai koefisien absorbsi bunyi untuk kedelapan bahan dapat ditabulasikan sebagaimana Tabel 2

Dari data sebagaimana diatas menunjukkan bahwa kemampuan peredaman terbesar diperoleh dari kayu akasia mangium yakni sebesar 0,13 dan diikuti oleh papan partikel tebal dengan nilai 0,127 dan kayu sengon sebesar 0,11 . Nilai terrendah diperoleh dari peredaman dengan bahan karton yang hanya mampu menghasilkan nilai koefisien peredaman sebesar 0,06.

Dari semua bahan yang digunakan, koefisien peredaman yang dihasilkan masih tergolong rendah karena belum mencapai 0,3 yang menurut Wahyudi et al. (2013) merupakan batas terendah peredam yang baik.

\section{B. Pembahasan}

Guna mendapatkan hasil yang lebih akurat tentang perbedaan nilai hasil antar perlakuan yang dilakukan dalam penelitian, Tabel 3 menunjukkan analisis sidik ragam yang memaparkan signifikansi perlakuan terhadap delapan bahan insulasi tersebut.

Dari Tabel 3 tampak terdapat perbedaan perlakuan yang menunjukkan hal yang sangat signifikan, sehingga memerlukan uji lanjut sehingga diketahui perlakuan mana yang menghasilkan sgnifikansi tersebut.

Tabel 4 membuktikan adanya signifikansi pada bahan peredam yang digunakan. Dengan demikian, perlakuan 3 (bahan kayu akasia) merupakan bahan insulasi yang memperoleh signifikansi terbanyak, berbeda dengan bahan lainnya. Dari uji lanjut tersebut dapat diasumsikan bahwa meski koefisien peredaman semua bahan penelitian masih dibawah nilai yang diharapkan, namun bahan akasia mangium menjadi bahan yang memperoleh nilai koefisien peredaman tertinggi.

Tabel 3. Anova Delapan Bahan Peredaman

\begin{tabular}{lccccc}
\hline SV & DB & JK & KR & F hitung & F0.05/0.01 \\
\hline Perlakuan & 7 & 0.049 & 0.0071 & $4.5670^{* *}$ & 2.013 \\
Galat & 72 & 0.112 & 0.0015 & & 2.666 \\
Total & 79 & 0.162 & & & \\
\hline
\end{tabular}

Tabel 4. Uji Beda Terkecil (LSD) Setiap Perlakuan

\begin{tabular}{ccrrrrrr}
\hline Perlakuan & 2 & 3 & 4 & 5 & 6 & 7 & 8 \\
\hline 1 & -0.013 & $-0.073^{* *}$ & $-0.055^{* *}$ & -0.034 & -0.019 & $-0.069^{* *}$ & -0.030 \\
2 & - & $-0.059^{* *}$ & $-0.041^{*}$ & -0.020 & -0.005 & $-0.056^{* *}$ & -0.016 \\
3 & - & - & 0.017 & $0.038^{*}$ & $0.053^{* *}$ & 0.003 & $0.042^{*}$ \\
4 & - & - & - & 0.020 & $0.036^{*}$ & -0.014 & 0.024 \\
5 & - & - & - & - & 0.015 & -0.035 & 0.004 \\
6 & - & - & - & - & - & $-0.050^{* *}$ & -0.011 \\
7 & - & - & - & - & - & - & $0.039^{*}$
\end{tabular}

Keterangan: notasi ${ }^{*}$ dan ${ }^{* *}$ masing-masing menunjukkan hal yang signifikan dan sangat signifikan, untuk beda pasangan rataan perlakuan, selain itu adalah hal yang non signifikan. 


\begin{abstract}
Kayu Akasia mangium memperoleh koefisien tertinggi diduga karena kerapatannya yang tinggi, dan kerapatan ini mempengaruhi kemampuan peredaman karena lebih banyak pori kayu yang mampu menahan laju getaran dari sumber suara. Hal tersebut sangat berbeda dengan bahan karton yang disamping tipis, kemampuan meredam juga sangat rendah karena kemampuan menahan getarannya rendah.
\end{abstract}

\section{KESIMPULAN DAN SARAN}

\section{A. Kesimpulan}

Nilai koefisien peredaman tertinggi diperoleh dari bahan kayu Akasia mangium, kemudian berturut-turut diikuti oleh papan partikel tebal, papan partikel tipis, kayu sengon, kayu lapis, gypsum, tatakan telur dan karton, dengan rentang nilai 0,13 sampai 0,06 .

\section{B.Saran}

Perlu melaksanakan penelitian sejenis dengan bahan yang lebih beragam sehingga diperoleh bahan insulasi terbaik terutama dari bahan daur ulang ataupun pemanfaatan limbah pertanian dan kehutanan.

\section{DAFTAR PUSTAKA}

Djalante S. 2010. Analisis Tingkat Kebisingan di Jalan Raya dengan Alat Pemberi Isyarat. Jurnal Smartek Vol 8 No.4. Nov. 2010.
Giri, IBD. 208. Kuat Tekan dan Modulus Elastisitas Beton dengan Penambahan Styrofoam. Jurnal IImiah Teknik Sipil Vol 12, No.1.

Hidayati, Nurul. 2007. Pengaruh Arus Lalu Lintas Terhadap Kebisingan. Universitas Muhammadiyah Surakarta.

Lee, $Y$ and Changwhan Joo, 2003. Sound Absorption Properties of Recycled Polyester. Autex Researc Journal Vol.3 No. 2, 2013.

Puspitarini, Y. Fandi M., Agus Y. Koefisien Serap Bunyi Ampas Tebu sebagai Bahan Peredam Suara Jurusan Fisika, Fakultas Matematika dan IImu Pengetahuan Alam, Universitas Negeri Semarang (Unnes) Jurnal Fisika Vol. 4 No. 2, Nopember 2014.

Sarwono, J. 2008. Wawancara Absorpsi dan Refleksi Gelombang Suara. https://jokosarwono.wordpress.com/200 8/03/14/wawancara-virtual-tentangabsorpsi-dan-refleksi-gelombang-suaradalam-ruang/, diunduh 18 Desember 2020.

Simatupang, Rio dkk. 2011. Pengaruh Penggunaan Serat Waru Sebagai Penguat Komposit terhadap Serapan Bunyi. Universitas Negeri Surabaya.

Wahyudi, H. Syakbaniah, Y. Darvina. 2013. Pengaruh Kerapatan Terhadap Koefisien Absorbsi Bunyi Papan Partikel Serat Daun Nenas (Ananas comosus L Merr). Pillar Of Physics 1: 44-51.

Wijaya, SN. 20015. Efek Peredaman Beton Styrofoam Ringan dengN Semen Portland. FT Univ Gajah Mada, Jogyakarta. 